\title{
Comparison of Placenta PCR and Maternal Serology of Aborted Women for Detection of Toxoplasma gondii in Ardabil, Iran
}

\author{
Somaie Matin', Gholamreza Shahbazi,, , Shervin Tabrizian Namin³, Rouhallah Moradpour', Farideh Feizi", \\ Hadi Piri-dogahe ${ }^{5}$ \\ 'Department of Internal Medicine, Ardabil University of Medical Sciences, Ardabil, Iran; ${ }^{2}$ Department of Parasitology and Mycology, Faculty of \\ Specialized Veterinary Science, Islamic Azad University, Science and Research Branch, Tehran, Iran; ${ }^{3}$ Department of Obstetrics and Gynecological, \\ Ardabil University of Medical Sciences, Ardabil, Iran; ${ }^{4}$ Ardabil University of Medical Sciences, Ardabil, Iran; ${ }^{5}$ Department of Microbiology, Ardabil \\ University of Medical Sciences, Ardabil, Iran
}

\begin{abstract}
Primary maternal infection with toxoplasmosis during pregnancy is frequently associated with transplacental transmission of the parasite to the fetus. This study was conducted to test the utility of PCR assay to detect recent infections with Toxoplasma in aborted women at various gestational ages who referred to Obstetrics and Gynecology Department of Alavi Hospital in Ardabil during 2014 and 2016. Two hundred women with a history of single or repeated abortion were investigated in this study. Blood samples were tested for specific anti-Toxoplasma IgM and IgG antibodies by ELISA. According to the results, $53.5 \%$ of the women under study were positive for anti-Toxoplasma antibodies: $4.0 \%$ of them had $\operatorname{lgM}, 43.0 \%$ had IgG, and 6.5\% had both IgM and IgG. Subsequently, Nested-PCR analysis was used to detect $T$. gondii DNA in the placenta of subjects. In $10.5 \%$ of the women, the results were positive for 529 bp element of $T$. gondii. Among them, 5 (23.8\%) cases were lgM positive, 1 (4.8\%) case was lgG positive, and 11 (52.4\%) were both lgM and lgG positive. In 4 (19.0\%) patients, none of the antibodies were found to be positive. In total, 16 patients had positive results in both ELISA and PCR methods, and 174 cases had negative results for new infection. The findings of this study revealed that $T$. gondii might be one of the significant factors leading to abortion, and that the analysis of placenta can be important in order to achieve increased detection sensitivity.
\end{abstract}

Key words: Toxoplasma gondii, abortion, blood, nested-PCR, ELISA, Iran

\section{INTRODUCTION}

Toxoplasmosis is a parasitic infection which is induced by Toxoplasma gondii and has various clinical symptoms [1]. Infection with this parasite occurs as the result of eating uncooked foods as well as water and vegetables contaminated with cat feces [2]. When a woman eats Toxoplasma oocysts or cysts for the first time during pregnancy, tachyzoites spread all over the body through the blood [3]. The fetus becomes infected with the Toxoplasma parasite which enters its blood flow via the placenta. The infection of mother before pregnancy rarely puts the fetus in danger unless in patients with immune system de-

- Received 13 July 2017, revised 26 November 2017, accepted 27 November 2017.

*Corresponding author (rzshhbz@yahoo.com)

(c) 2017, Korean Society for Parasitology and Tropical Medicine

This is an Open Access article distributed under the terms of the Creative Commons Attribution Non-Commercial License (http://creativecommons.org/licenses/by-nc/4.0) which permits unrestricted non-commercial use, distribution, and reproduction in any

medium, provided the original work is properly cited. ficiencies [4].

Congenital toxoplasmosis generally occurs when the mother gets infected with Toxoplasma newly during pregnancy which can lead to various infections in the fetus and infant such as abortion, stillbirth, and live birth of a child with classic symptoms of toxoplasmosis like hydrocephaly, microcephaly, cerebral calcifications, and retinochoroiditis [5,6]. The risk of transfer after primary infection varies from 25\% (in the first trimester) to $65 \%$ (in the last trimester); however, the younger fetuses are more susceptible to this infection [7].

In Iran, the rate of abortion as the result of toxoplasmosis is unknown. Most of the studies to date about the abortions suspected to be the result of Toxoplasma have been conducted based on the serological findings about mothers. In this study, we investigated the use of nested PCR (nPCR) method for the isolation of 529 bp element in the placenta and ELISA method for the detection of anti-Toxoplasma antibodies in mothers who had experienced abortion in Ardabil, north-west of Iran. 


\section{MATERIALS AND METHODS}

In this study, we investigated 200 women who had experienced abortion in different gestational ages and referred to Obstetrics and Gynecology Department of Alavi Hospital in Ardabil during 2014 and 2016. The study protocol was approved by the scientific committee of Ardabil University of Medical Sciences with the approval code of 9206.

\section{Sample collection}

Three $\mathrm{ml}$ of venous blood was drawn from each patient and their serums were isolated. About $20 \mathrm{~g}$ of the placenta samples of the same patients were cut in sterilized conditions and stored together with the serum samples at the temperature of $-20^{\circ} \mathrm{C}$ until conducting the tests. The sera of all cases were tested for the presence of specific IgM and IgG anti-Toxoplasma antibodies via ELISA kits (Biokit, Barcelona, Spain) according to the manufacturer's instructions. For each patient, a questionnaire including the mother's age, gestational age, and the history of prior abortion was completed.

\section{DNA extraction and PCR detection:}

T. gondii DNA was extracted from the placenta of the aborted women using the QIAamp DNA mini kit (Qiagen, Courtaboeuf, France) according to the manufacturer's instructions.

Detection procedures sets were used for amplifying fragments of 529 bp element as described by Su et al. [8]. The external primers were Tox-8: GACGTCTGTGTCACGTAGAAAG and Tox5: CTGCAGACACAGTGCATCT GG ATT producing an amplified product of $450 \mathrm{bp}$. Internal primers were Tox-9: AGGAGAGATATCAGGACTGTAC and Tox-II: GCGTCGTCTCGTCTAGATCG producing an amplified product of $162 \mathrm{bp}$. The reactions mixture contained $40 \mu \mathrm{l}$ mixture of $5 \mu \mathrm{l} 10 \times$ PCR buffer, $4 \mu \mathrm{l} 25$ $\mathrm{mM} \mathrm{MgCl} 2,4 \mu \mathrm{l}$ dNTPs (2.5 mM each), $0.2 \mu \mathrm{l} \mathrm{FastStart} \mathrm{Taq} \mathrm{(5}$ $\mathrm{U} / \mu \mathrm{l}), 0.30 \mu \mathrm{l}$ external forward primer $(50 \mu \mathrm{M})$, and $0.30 \mu \mathrm{l} \mathrm{ex}$ ternal reverse primer $(50 \mu \mathrm{M})$ added with $10 \mu \mathrm{l}$ template DNA. The following conditions were used to amplify the target DNA: one cycle of $5 \mathrm{~min}$ initial denaturation at $95^{\circ} \mathrm{C}$ followed by 30 cycles at $94^{\circ} \mathrm{C}$ for $30 \mathrm{sec}, 55^{\circ} \mathrm{C}$ for $1 \mathrm{~min}$, and $72^{\circ} \mathrm{C}$ for $2 \mathrm{~min}$. Amplification was performed using thermal cycler. All PCR products, regardless of the presence or absence of a visible band were subjected to a second round of PCR.

The nPCR reaction was performed using $5 \mu$ of the first PCR reaction in a mixture containing the inner primers at final concentration of $45 \mu \mathrm{l}$ mixture of $5 \mu \mathrm{l} 10 \times$ PCR buffer, $4 \mu \mathrm{l} 25$
$\mathrm{mM} \mathrm{MgCl}_{2}, 4 \mu \mathrm{dNTPs}$ (2.5 mM each), $0.2 \mu$ Fast Start Taq (5 $\mathrm{U} / \mu \mathrm{l}), 0.30 \mu \mathrm{l}$ nested forward primer $(50 \mu \mathrm{M})$, and $0.30 \mu \mathrm{l}$ nested reverse primer $(50 \mu \mathrm{M})$. Amplification was carried out at $95^{\circ} \mathrm{C}$ for $5 \mathrm{~min}$ (one cycle), then followed by 30 cycles at $94^{\circ} \mathrm{C}$ for $30 \mathrm{sec}, 55^{\circ} \mathrm{C}$ for $1 \mathrm{~min}$, and $72^{\circ} \mathrm{C}$ for $1 \mathrm{~min}$. The amplification products were detected by gel electrophoresis using $2 \%$ agarose gel in $1 \times$ Tris-borate-EDTA buffer. DNA bands were visualized in the presence of ultraviolet light following the staining with $0.5 \%$ ethidium bromide.

\section{Analysis of data}

The minimum and maximum range of Toxoplasma-induced abortion prevalence and the level of agreement (kappa statistics, SPSS 16, Chicago, Illinois, USA) were measured to analyze any association between congenital infection by $T$. gondii and the 2 different diagnostic techniques employed [11]. The chi-square test was used to analyze the association between congenital infection and the demographic characteristics of the mothers who had abortion.

\section{RESULTS}

\section{Demographic characteristics of mothers who had abortion}

The age range of the patients included in the study was 1641 years and their mean age was 30.5 years. Forty-three subjects were under 20 years old, 88 of them were between 20 and 30 years old, and 69 of them were over 30 years old. According to the data collected, most of the patients (53.0\%) were in the first trimester of pregnancy. The patients in the second and third trimester of pregnancy were $31.0 \%$ and $16.0 \%$, respectively (Table 1). Moreover, $71.0 \%$ of them did not have prior abortion experience. Hypothyroidism, diabetes, and allergies were found respectively in 8 (4.0\%), 9 (4.5\%), and 5 (2.5\%) patients while 178 cases $(84.0 \%)$ had no history of diseases except miscarriage.

\section{Serology}

In this study, samples from the women who had abortion were investigated for the presence of anti-Toxoplasma IgG and IgM antibodies using ELISA method. The analysis indicated positive results for anti-Toxoplasma antibodies in $53.5 \%$ of the patients: $43.0 \%$ tested positive for only anti-Toxoplasma IgG antibodies, 6.5\% tested positive for both anti-Toxoplasma IgG and IgM antibodies, and $4.0 \%$ indicated positive results for 
Table 1. Demographic characteristics of mothers who had abortion and results of different diagnostic techniques

\begin{tabular}{|c|c|c|c|c|c|c|c|c|c|c|}
\hline & & \multirow{2}{*}{ No. } & \multicolumn{2}{|c|}{ PCR } & \multicolumn{4}{|c|}{ ELISA } & \multicolumn{2}{|c|}{ Both PCR and ELISA } \\
\hline & & & Positive & Negative & $\operatorname{lgM}^{+}$ & $\lg ^{+}$ & $\operatorname{lgG} \& \lg M^{+}$ & $\lg$ & Positive ${ }^{a}$ & Negative $^{b}$ \\
\hline Age groups (year) & $\begin{array}{l}\leq 20 \\
20-30 \\
\geq 30\end{array}$ & $\begin{array}{l}43 \\
88 \\
69\end{array}$ & $\begin{array}{r}4 \\
10 \\
7\end{array}$ & $\begin{array}{l}39 \\
78 \\
62\end{array}$ & $\begin{array}{l}2 \\
4 \\
2\end{array}$ & $\begin{array}{l}13 \\
31 \\
42\end{array}$ & $\begin{array}{l}3 \\
5 \\
5\end{array}$ & $\begin{array}{l}25 \\
48 \\
20\end{array}$ & $\begin{array}{l}3 \\
8 \\
6\end{array}$ & $\begin{array}{l}23 \\
47 \\
19\end{array}$ \\
\hline Gestational age & $\begin{array}{l}\text { 1st trimester } \\
\text { 2th trimester } \\
\text { 3th trimester }\end{array}$ & $\begin{array}{r}106 \\
62 \\
32\end{array}$ & $\begin{array}{r}11 \\
8 \\
2\end{array}$ & $\begin{array}{l}95 \\
54 \\
30\end{array}$ & $\begin{array}{l}4 \\
4 \\
0\end{array}$ & $\begin{array}{l}27 \\
28 \\
31\end{array}$ & $\begin{array}{l}6 \\
6 \\
1\end{array}$ & $\begin{array}{r}69 \\
24 \\
0\end{array}$ & $\begin{array}{l}8 \\
8 \\
1\end{array}$ & $\begin{array}{r}67 \\
22 \\
0\end{array}$ \\
\hline History of abortion & $\begin{array}{l}\text { Yes } \\
\text { No }\end{array}$ & $\begin{array}{r}58 \\
142\end{array}$ & $\begin{array}{r}3 \\
18\end{array}$ & $\begin{array}{r}55 \\
124\end{array}$ & $\begin{array}{l}0 \\
8\end{array}$ & $\begin{array}{l}31 \\
55\end{array}$ & $\begin{array}{r}2 \\
11\end{array}$ & $\begin{array}{l}25 \\
68\end{array}$ & $\begin{array}{r}1 \\
16\end{array}$ & $\begin{array}{l}23 \\
66\end{array}$ \\
\hline
\end{tabular}

${ }^{a} P C R$ positive and ELISA positive (IgG positive+lgM positive+lgG and IgM positive).

${ }^{\mathrm{b} P C R}$ negative and ELISA negative (Ig negative).

Table 2. ELISA and nested PCR results in samples

\begin{tabular}{llrcr}
\hline \multirow{2}{*}{ Methods } & & \multicolumn{2}{c}{ nPCR } & \multirow{2}{*}{ No. } \\
\cline { 3 - 4 } & & Positive & Negative & \\
\hline ELISA & IgG Positive & 1 & 85 & 86 \\
& IgM Positive & 5 & 3 & 8 \\
& IgG \& IgM Positive & 11 & 2 & 13 \\
& Negative & 4 & 89 & 93 \\
& No. & 21 & 179 & 200 \\
\hline
\end{tabular}

only anti-Toxoplasma IgM antibodies (Tables 1, 2).

\section{PCR and $\mathrm{nPCR}$}

In this study, in addition to serological diagnosis method, PCR method was also used to investigate the presence of Toxoplasma DNA in the placenta of the patients under study. All PCR products in the first round were included in the second round of PCR. Using this method, from among the 200 patients under study, Toxoplasma infection was diagnosed in 21 (10.5\%) samples based on nPCR (Fig. 1). In 17 of the samples with positive results, both the $450 \mathrm{bp}$ and the $162 \mathrm{bp}$ bands were detectable, but in 4 of them, just the 162 bp band was detected in nPCR. Among the 21 patients for whom nPCR was reported to be positive, 5 (23.8\%) cases were IgM positive, 1 (4.8\%) was IgG positive, and 11 (52.4\%) were both IgM and IgG positive. In 4 (19.0\%) patients, none of the antibodies were found to be positive.

\section{Correlation between demographic characteristics of mothers and infection}

ELISA and nPCR results and data from questionnaires were analyzed employing chi-square statistical test with $95 \%$ confidence interval using SPSS software version 16. No significant association was found between the presences of Toxoplasma DNA and mother's age $(P=0.23)$, history of abortion $(P=0.08)$,

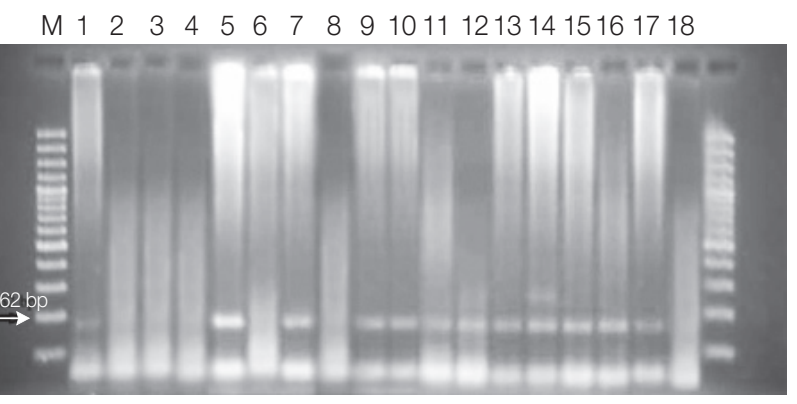

Fig. 1. Agarose gel electrophoresis of nested PCR products of tissue samples of aborted placenta with the internal 529 bp element primers. Lane M, molecular marker; lane 1, T. gondii positive control (type 1; RH strain); lane 18 negative control; lane 2-17 samples.

and gestational age $(P=0.16)$. There was also no significant association between positive serological samples (IgM positive and both IgM and IgG positive) and mother's age $(P=0.18)$, history of abortion $(P=0.06)$, and gestational age $(P=0.15)$.

\section{Agreement between ELISA and $\mathrm{nPCR}$ methods}

Among all samples, maternal seroprevalence (anti-Toxoplasma IgM antibodies) was 5.8\% to $14.2 \%$ (95\% confidence interval) and the estimated abortion prevalence associated with T. gondii based on PCR was calculated to be from $6.3 \%$ to $14.7 \%$ ( $95 \%$ confidence interval). Results show moderate logical agreement between the 2 different tests $(\kappa=0.44)$. (A value of kappa equal to +1 implies perfect agreement between the 2 raters, while that of -1 implies perfect disagreement) [9].

\section{DISCUSSION}

The detection of infective agents in pregnancy is very important since they not only threaten the mother's health but also cause fetal abnormalities [10]. According to the findings of the 
previous studies, mother's infection in the first and second trimester might lead to the death of fetus in $5 \%$ and $2 \%$ of the cases, respectively [1-11]. The incidence rate of congenital toxoplasmosis is approximately 1.5 cases per 1,000 live births, so the estimated global incidence of congenital toxoplasmosis is 190,100 cases per year [12].

A series of techniques are required to make a definitive diagnosis in the abortions occurred as the result of toxoplasmosis [13]. Suzuki et al. [14] conducted the evaluation of IgM via isolating the SAG 1 gene of Toxoplasma in placenta and concluded that the evaluation of placenta in order to detect Toxoplasma genome can be very helpful for the rapid diagnosis of congenital toxoplasmosis.

In 2000, the 200- to 300-fold repetitive 529 bp DNA fragment was identified in $T$. gondii genome and researchers reported high sensitivity and great feature of PCR method in detecting this parasite [15]. In 2003, 529 bp DNA fragment was introduced as a new alternative for $18 \mathrm{~S}$ ribosomal DNA and B1 targets in detecting Toxoplasma DNA in congenital toxoplasmosis [16]. The rate of Toxoplasma-induced abortion has been different in studies (18.3\% in Egypt [17], 5.3\% in Brazil [18], $15.5 \%$ in Isfahan, Iran [19], 14.4\% in Shiraz, Iran [20], and $11.0 \%$ in France [21]. Sarkari et al. [22] analyzed the aborted fetuses for which the PCR test was positive using immunohistochemistry (IHC) method and did not observe any cyst or tachyzoitein them. The reason for this might be the low number of parasites in the aborted tissues.

In our study, a moderate agreement between the 2 different tests was found with $95 \%$ confidence interval $(\kappa=0.44)$. This finding indicates the need for more research in order to shed light on the methods of infection transfer and also the level of transfer after getting infected.

Although getting serological tests is one of the main diagnostic methods used for the detection of toxoplasmosis, it has many limitations. This method might not be able to detect special anti-Toxoplasma antibodies during the active phase of infection since these antibodies might not be produced until several weeks after parasitaemia. Moreover, this method might be unsuccessful in detecting $T$. gondii infection in individuals with immune system deficiencies due to the lack of appropriate antibodies production. Therefore, using PCR method in detecting infection with $T$. gondii obviates the problems encountered when using serological methods, and also when dealing with patients having complicated problems. Thus, the results obtained simultaneously from PCR and ELISA meth- ods can definitively confirm the infection [23].

The presence of Toxoplasma DNA in 4.3\% of the women for whom the results of serological test were negative might suggest the existence of a new infection at the time of getting samples which shows that the immune system either has not been able to produce enough immunoglobulins to detect it in serology method or suffers from degrees of immunodeficiency. A positive result of a serological test only shows the presence of an infection whereas the direct detection of $T$. gondii in clinical samples can confirm the presence of parasites which themselves can be primary, reactivated, or chronical infections [24]. Our findings indicate that toxoplasmosis is a big danger and a main risk factor in increasing the probability of abortion in pregnant women in this part of Iran. Therefore, we recommend that in order to increase detection sensitivity, molecular test of placenta be conducted for each abortion even if the results of serological tests are negative.

\section{ACKNOWLEDGMENTS}

This study was supported by the financial grant of the Research Department of Ardabil University of Medical Sciences, Iran, which is gratefully acknowledged.

\section{CONFLICT OF INTEREST}

We have no conflict of interest related to this study.

\section{REFERENCES}

1. Montaya JG, Liesenfeld O. Toxoplasmosis. Lancet 2004; 363 : 1965-1976.

2. Boothroyd JC. Toxoplasmosis. In Moselio S. Encyclopedia of Microbiology. 3rd ed. Oxford, UK. Elsevier. 2009, pp 732-743.

3. Dubey JP, Jones JL. Toxoplasma gondii infection in humans and animals in the United States. Int J Parasitol 2008; 38: 1257-1278.

4. Mitchell CD, Erlich, SS, Mastrucci MT, Hutto, SC, Parks, WP, Scott GB. Congenital toxoplasmosis occurring in infants perinatally infected with human immunodeficiency virus 1 . Pediatr Infect Dis J 1990; 9: 512-518.

5. McAuley J, Boyer KM, Patel D, Mets M, Swisher C, Roizen N, Wolters C, Stein L, Stein M, Schey W, Remington J, Meier P, Johnson D, Heydeman P, Holfels E, Withers S, Mack D, Brown C, Patton D, McLeod R. Early and longitudinal evaluations of treated infants and children and untreated historical patients with congenital toxoplasmosis: the Chicago collaborative treatment trial. Clin Infect Dis 1994; 18: 38-72. 
6. Remington JS, McLeod R, Thulliez P, Desmonts G. Toxoplasmosis. In Remington JS, Klein JO, Wilson CB, Baker CJ eds, Infectious Diseases of the Fetus and Newborn Infant. Philadelphia, USA. Elsevier Saunders. 2006, pp 947-1091.

7. Robbins JR, Zeldovich VB, Poukchanski A, Boothroyd JC, Bakardjiev AI. Tissue barriers of the human placenta to infection with Toxoplasma gondii. Infect Immun 2012; 80: 418-428.

8. Su C, Dubey JP. Toxoplasma. In Dongyou L ed, Molecular Detection of Foodborne pathogen. London, UK. Taylor and Francis. 2009, pp 741-753.

9. Fleiss JL, Levin B, Paik MC. Statistical Methods for Rates and Proportions. 3rd ed. New Jersey, USA. John Wiley and Sons. 2013.

10. Sterkers Y, Ribot J, Albaba S, Issert E, Bastien P, Pratlong F. Diagnosis of congenital toxoplasmosis by polymerase chain reaction on neonatal peripheral blood. Diagn Microbiol Infect Dis 2011; 71: $174-176$.

11. Dubey JP. Toxoplasmosis. In Collier L, Sussman M eds. Topley \& Wilson's Microbiology and Microbial Infections: Virology. London, UK. Hodder Arnold. 2005, pp 303.

12. Torgerson PR, Mastroiacovo P. The global burden of congenital toxoplasmosis: a systematic review. Bull World Health Organ 2013; 91: 501-508.

13. Jones CD, Okhravi N, Adamson P, Tasker S, Lightman S. Comparison of PCR detection methods for B1, P30, and 18S rDNA genes of $T$. gondii in aqueous humor. Invest Ophthalmol Vis Sci 2000; 41: 634-644.

14. Suzuki Y, Takemoto O, Arai H, Goto M, Yamada J, Morimoto K, Nakayama M, Futagi Y, Yano A. A case of congenital toxoplasmosis confirmed by detection of Toxoplasma gondii in placenta. No To Hattatsu 1998; 30: 411-416 (in Japanese).

15. Homan WL, Vercammen M, De Braekeleer J, Verschueren H. Identification of a 200- to 300-fold repetitive 529 bp DNA frag- ment in Toxoplasma gondii, and its use for diagnostic and quantitative PCR. Int J Parasitol 2000; 30: 69-75.

16. Filisetti D, Gorcii M, Pernot-Marino E, Villard O, Candolfi E. Diagnosis of congenital toxoplasmosis: comparison of targets for detection of Toxoplasma gondii by PCR. J Clin Microbiol 2003; 41: 4826-4828.

17. Kamal AM, Ahmed AK, Abdellatif MZ, Tawfik M, Hassan EE. Seropositivity of toxoplasmosis in pregnant women by ELISA at Minia university hospital, Egypt. Korean J Parasitol 2015; 53: 605-610.

18. Da Silva MG, Vinaud MC, de Castro AM. Prevalence of toxoplasmosis in pregnant women and vertical transmission of Toxoplasma gondii in patients from basic units of health from Gurupi, Tocantins, Brazil, from 2012 to 2014. PLoS One 2015; 10: 1-15.

19. Hoveida L, Doudi M, Setorki M. Evaluation of Toxoplasma gondii abortion cases by PCR teqnique in Isfahan, Iran. IJBPAS 2014; 3 : 524-531.

20. Asgari Q, Fekri M, Monabati A, Kalantary M, Mohammadpour I, Motazedian MH, Sarkari B. Molecular genotyping of Toxoplasma gondii in human spontaneous Aborted fetuses in Shiraz, southern Iran. Iran J Public Health 2013; 42: 620-625.

21. Nowakowska D1, Gołab E, Czichos E, Krekora M, Wilczyński J. Detection of Toxoplasma gondii in human placenta by PCR and placental histologic findings. Wiad Parazytol 2002; 48: 301-309 (in Polish).

22. Sarkari B, Asgari Q, Mirzaee S. Evaluation of immunohistochemistry and PCR in diagnosis of toxoplasma infection in tissues of human aborted fetuses. Zahedan J Res Med Sci 2013; 15: 42.

23. Abbas HH, Alasadiy YD, Al-tememi MB. Detection Toxoplasma gondii by real-time PCR in abortive and pregnant women in Almuthanna province. J Inter Acad Res Mult 2014; 2: 310-317.

24. Bastien P. Molecular diagnosis of toxoplasmosis. Trans R Soc Trop Med Hyg 2002; 96 (suppl): 205-215. 
